位か)によりレスポンスに差が生ずる。３倍回転管球を 用いることにより振動が生ずるため床や装置全体のガタ を調べておくべきである.

\section{I.I. 出力螢光面の改良}

\section{島津铱作所医用技術部 ○橋詰辰夫 ・吉村公男}

I.I. の画質を向上させるために, I.I.の出力螢光面の新 規な製作法を開発し，良好な結果が得られた。

この製作法は遠心力を用いて有機溶剤中に分散させた 螢光体粒子を，基板上に設けたら゙ル膜中に圧入して螢光 面を作る方法である。螢光面沈着工程中に水を全く使用 しないため粒子の凝集が少なく緻密で薄い營光膜が形成 される.

その結果, 解像力, コントラストが高く，また固定雑 音（粒状性）が少ない I.I. 出力螢光面が得られた。

試作品をI.I. 亿組み入れ評価した結果，従来の出力螢 光面のむのより良い性能が得られた。

\section{I.I. 間接撮影システムのコントラスト評価} 東芝医用機器事業部

○藤井干蔵・安原 弘・青木久敏

$\mathrm{X}$ 線写真のコントラストの新しい評価方法として, $\mathrm{X}$ 線スペクトルを基にした方法を考察した．今回コントラ ストファントムなるあのを武作し， I.I. 間接系における 管電圧特性, 被写体厚特性, グリッド效果について，実 験を行ない，本評価方法の有效性を確認した，本方法の 利点は，(1)コントラストの定量化，絶対評価ができる.

(2)ある系でのコントラストの上限值，すなわちコントラ ス卜改善の目標值が理論的に求まる。 (3)簡単に測定がで きる，等である．今後は，X線TV葠台装置の評価，グ リッドの評価，X線シネ撮影系のコントラスト評価等へ の応用を考えている.

\section{6. 二方向シネ撮影におけるブランキングュニットの 効果について}

国立循環器病センター放射線竛療部

○大西義隆・片淵哲郎・与小田一郎 若松孝司・栄組一男 $\cdot$ 横山博典 佐野敏也

二方向シネ撮影において，ブランキングユニットは， 側方散乱線カブリの除去に使用されている。私たちは， ブランキング効果の解析を I.I. 二次螢光面の出力波形を 直接測定するととにより行なった。

ブランキングにより側方散乱線及び，I.I. の残光のほ 亡れどがカットされるが，ブランキング時間がX線パル ス高の70\%である撮影時間と同じであるため，X線パル
スの波尾の影㗽があるものと考えられる，画質の点にお いては，ウログラフィン入りチューブでコントラストを 測定した結果，モノプレーン時に比べてブラキング有で 約 5\%，無で約 $15 \%$ の低下があった。

197. X線管 $\mathrm{v}-\mathbf{i}$ 特性と $X$ 線出力についてくターゲット角 度との関係)

東邦大学医学部付属大橋病院湤身線科

○宮崎 茂・松谷一雄・新木 操

東邦大学医学部放射線医学教室 青柳泰司 立正佼成会附属佼成病院放射線室 斎藤一应

〔目的〕 X線管電流特性は実焦点面積によって变わる ため，同一実效集点のX線管でもターゲット角度によっ て変わる：とのととから同一実効焦点X線管 $18^{\circ}$ と $16^{\circ}$ 管のX線管 v-i 特性々X線出力の関係について調べた。

〔測定方法】X線管 v-i 特性はオンロスコープより求 め, X線出力は螢光量計と線量計より求めた。

〔測定結果】 (1) XX X 線管 v-i 特性, $60 \mathrm{kV}, 500 \mathrm{~mA}$ 亿 おいて $18^{\circ}$ 管の管電流波高值は $810 \mathrm{mAp}, 16^{\circ}$ 管は 720 $\mathrm{mAp}$ であった. (2) X線出力, 付加フィルタ Al $10 \mathrm{~m}$ $\mathrm{m}, 60 \mathrm{kV}, 500 \mathrm{~mA}$ 亿㐨认て $\mathrm{F} / \mathrm{mAs}$ \& $18^{\circ}$ 管 $0.29,16^{\circ}$ 管0.24であった。

〔結論】同一容量, 同一焦点のX線管においててター ゲット角度の違いがX線管 v-i 特性に影響し低電圧大電 流ほどX線出力む異なる。

198. シネ撮影用 $9 / 7$ 时新形メタル I.I.

東芝電子事業部

○荒牧成光・传野 暂・杉山正弘 石渡久男 $\cdot$ 原尾紀男

循環器のシネ撮影用X線 I.I. として, X線入射空材料 が薄い金属板でできた $9 / 7$ 时メタル I.I. を開発した．従 来の X-I.I. はX線入射空材料が $3 \sim 4 \mathrm{~mm}$ 厚の ガラスで あったのに対して，新形メタル I.I.は $250 \mu \mathrm{m}$ 厚のチタ ニゥムを用いた。 入力㝘での散乱線は板厚が薄い程少な くなるため，乙れを用いたX線 I.I. は散乱X線が減少し て画像のコントラストが大湢に向上し，之くに高電圧領

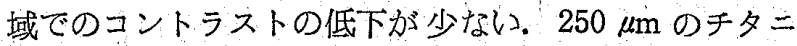
ウムを用いたととにより，X線透過特性すさらによくな る.

てのようにして䦎発したX線 I.I は循環器䛦断分野て のコントラストが強調され, シネ撮影で鮮明な画像を得 ることができる.

\section{座長集約}

190席 ターゲット襄面を黒化して陽極温度を赤外線 